\title{
Study on the Innovation of Ideological and Political Education in Colleges and Universities
}

\author{
Qinying Yuan
}

Ideological and Political Department Xi'an Peihua University Xi 'an, shaanxi province, China

\begin{abstract}
The innovation of Ideological and political theory teaching in Colleges and universities must hold back the development direction of higher education reform. On the basis of the achievements of practical teaching of Ideological and political courses in Colleges and universities, by giving full play to the role of students as the main body, playing the leading role of Teachers, and effectively integrating ideological and political education resources, ideological and political teaching in Colleges and universities can play a better role.
\end{abstract}

Keywords: colleges and universities; ideological and political; educational work.

\section{Introduction}

With the rapid development of society, the demand for talents is increasing day by day. At the same time, the demand for their comprehensive quality is also increasing. College students are a special group, the group with the highest level of knowledge, the most active thinking, the most representative, the most receptive to new things, the most ideal and faith pursuit among the youth, and the most important reserve force for building socialism with Chinese characteristics. However, college students are still young and their thoughts are not stable and mature. It is the primary task of education to guide them to establish a correct world outlook, outlook on life and values. As early as September 2004, the CPC Central Committee and the State Council issued the opinions on Further Strengthening and improving the ideological and political education of college students (hereinafter referred to as the opinions). The opinion emphasizes that college students are very valuable human resources, the hope of the nation and the future of the motherland. Strengthening and improving the ideological and political education of college students and improving their ideological and political quality are of great significance for the overall implementation of the strategy of rejuvenating the country through science and education and strengthening the country through human resources. As the training base of talents, colleges and universities should cultivate high-quality college students who meet the needs of the society, and do a good job in Ideological and political work of college students. The author intends to combine his own work practice, on how to do a good job of Ideological and political work in Colleges and universities to talk about their own suggestions.

\section{The Current Situation of Ideological and Political Work in Higher Vocational Colleges}

Higher vocational colleges pay great attention to the ideological and political education work, and have carried out many useful explorations, which have achieved certain results. Generally speaking, the mainstream of the ideological and political situation of higher vocational college students is positive, healthy and upward. They love the party, patriotism, people and socialism, support the party's lines, policies and policies, and care about state affairs; they have a positive attitude to the development of the country since the reform and opening up; party and League organizations have a considerable influence on college students in higher vocational education, especially among contemporary college students, the proportion of Party organizations required to join is increasing year by year. However, the problems of Ideological and political education in higher vocational colleges are also obvious, mainly in the following aspects: 


\subsection{Attention Still Needs to be Improved}

The importance of Ideological and political education for students in some higher vocational colleges is not fully understood. They only regard ideological and political education as a routine task, fail to realize that it is a basic project of socialist spiritual civilization construction, fail to realize from a strategic height that ideological and political work is an important means to train students to be useful talents in socialist cause construction. It is under this guidance that many higher vocational colleges believe that ideological and political work can achieve its goal as long as students abide by school rules and disciplines and do not violate laws and disciplines.

\subsection{Imbalance of Ideological and Political Education Standardization}

At present, the imbalance of Ideological and political education standardization in Colleges and universities is mainly manifested in the following three aspects: first, the current ideological and political work fails to play an effective role, only in the superficial form. Although the post responsibilities of Ideological and political staff have been established, they seldom go deep into the student group to investigate and understand the current ideological trends of students. Second, the current ideological and political education is out of line with the teaching work and fails to make mutual compensation and cross penetration. The teaching teachers failed to integrate the relationship between teaching and education, nor did they integrate teaching with learning and teaching with pleasure. The classroom teaching was obviously lack of moral education penetration. Make ideological and political education the exclusive work of the head teacher.

\subsection{Lack of Performance Evaluation System of Ideological and Political Education}

At present, in some higher vocational colleges, the work evaluation of Ideological and political staff is only based on the attendance rate of students during class time, to see whether someone is absent from class, late or leave early; the accident rate of students, to see whether someone fights and makes trouble, illegal crime, etc.; the score of Ideological and political cultivation and basic legal examination, etc. The above shows that the evaluation system of Ideological and political education is extremely superficial, and it does not go deep into the essence of Ideological and political education.

\subsection{Absence of Ideals and Beliefs of Some Students}

College students are the builders and successors of China's future socialist cause. Although most of them have a high level of understanding of ideals and beliefs, a small number of students have faith crisis, lack of initiative and enthusiasm in learning, lack of ideal goals in life, spiritual decadence, ideological treason, and moral behavior anomie; pay attention to the immediate interests of individuals rather than social responsibility, pursue ease and pleasure, abandon hard work, and lack of unity and cooperation in their own way.

\subsection{Lack of Sense of the Times in Education Methods}

At present, the thoughts and values of college students are becoming more and more diversified after the reform and opening up. With the rapid development of information technology, the ideological and political education in Colleges and universities is facing both opportunities and challenges. Pornography, violence, murder and other bad information through the Internet to the current ideological and political education has brought unprecedented impact, seriously affecting the ideological health of college students. But at present, ideological and political education in some higher vocational colleges still follows the traditional paradigm, which is obviously out of line with the times. The ideological and political education in higher vocational colleges needs a long way to go. 


\section{A New Vision of Ideological and Political Education in Colleges and Universities}

\subsection{Inspire Contemporary College Students with Advanced Deeds in Real Life}

In the new historical period of accelerating the socialist modernization, China is in an important historical stage of building a two oriented society in an all-round way. While inheriting the essence of excellent ideological tradition, the development of spiritual civilization needs the power of moral model to promote. The ideological and political lecture hall needs to be led by active and healthy moral style pacesetters. It advocates learning from the advanced moral model individuals and using their As a case, the advanced deeds inspire the contemporary college students, give the new socialist moral fashion to thousands of families, and infiltrate the most basic civil moral norms into the work and daily life of the masses. Only for this can we set up a clear and correct banner in the whole society, create a new socialist moral fashion that knows honor and disgrace, builds a new style, and promotes harmony, so as to promote social masters. The smooth promotion of the core value system of righteousness is conducive to vigorously carrying forward the traditional virtues of the Chinese nation and the implementation of social equity and justice, so that contemporary college students can learn by example, catch up with goals, and get close to real life, strengthen social practice activities in learning, and gradually become a kind of conscious power and action. For example, we can use the advanced deeds of Guo Mingyi to sublimate Lei Feng's spirit again, so as to inspire college students, and let thousands of Guo Mingyi become their models of praise and imitation to devote themselves to life and practice to serve the society.

\subsection{Ideological and Political Life}

The traditional ideological and political education mostly arranges the work in the classroom or the step classroom, the practice proves that its effect is not obvious. Therefore, the ideological and political staff should often communicate with students after class, master the current ideological trends of students, and guide and educate students in accordance with the ideological and moral Anomies of different students, so as to achieve a targeted goal. In the daily management, the ideological and political staff should go deep into the students' life, go to the dormitories and libraries to understand the students, through informal talks to shorten the distance between teachers and students, and carry out effective ideological and political education, which can not only improve the relationship between teachers and students. And college students are happy to be educated. In the context of mutual understanding and trust, students should also be fully aware of themselves. Only in this context can students sincerely take out their current ideological confusion to the ideological and political staff, so that the ideological and political staff can find out the misunderstandings in the ideological and political aspects of students in time, so that the problems can be solved in time and avoid students' Ideological and political problems. In order to avoid affecting their correct scientific "Three Outlooks", the phenomenon of anomie appears.

\subsection{Leading with the Essence of Marxism in China}

The Sinicization of Marxism is to combine the basic principles of Marxism with the specific reality of China. Starting from reality and seeking truth from facts is an important part of the essence of Marxism in China. The concrete embodiment of promoting harmonious and all-round development is also an important goal and content of building a well-off society in an all-round way. In the historical process of the Sinicization of Marxism, especially the three historical leaps of the Sinicization of Marxism, it has set up the glorious banner of the Communist Party of China, demonstrated the theoretical level of the Communist Party of China, and showed strong vitality in the process of combining with the specific practice of our country. As we all know, China has a vast territory, a large number of ethnic groups, and unbalanced political and economic development, which leads to different universities in different regions. Therefore, in carrying out ideological and political work, we should practice the essence of Sinicization of Marxism, in line with the spirit of starting from reality and seeking truth from facts. At the same time, we should learn from and absorb 
advanced external experience. We must use the latest achievements of Sinicization of Marxism to arm the mind, guide practice and promote work, so as to ensure the healthy development of Ideological and political education in Colleges and universities along the correct socialist direction.

\subsection{Carry Forward the National Spirit and the Spirit of the Times}

The national spirit and the spirit of the times are the signs of a nation's vitality and cohesion. Holding high the banner of socialism with Chinese characteristics and carrying forward the spirit of patriotism is the eternal theme of Ideological and political work in Colleges and universities. National spirit is the most concentrated essence of a national cultural heritage. It is our party that leads the people of all ethnic groups in the country to continuously strengthen their national spirit in the longterm resistance to external humiliation. In the new era, the people of all ethnic groups in China have demonstrated the great spirit of the times in the reform and opening up, forming the essence of the times with emancipating the mind, seeking truth from facts and advancing with the times as the core. In the face of the development of multipolarity in the world, all kinds of thoughts are conflicting and merging with each other. Therefore, in order to enrich the country and strengthen the people, a country must carry forward the national spirit and the spirit of the times. Facing the current vigorous and innovative college students. We should focus on the national spirit with patriotism as the core and the spirit of the times education with reform and innovation as the core, guide them to strive for the great rejuvenation of the Chinese nation, to achieve the highest ideal of life. In order to build up a firm national self-esteem and self-confidence among the young students, enable them to uphold and carry forward the fine tradition of patriotism as the core, consciously safeguard the national interests and form noble national feelings in their daily actions, the ideological and political workers must take the national spirit education with patriotism as the core as the main channel of Ideological and political education for college students, and carry forward and cultivate it. Education of national spirit is the primary task of campus culture construction. So that a strong sense of patriotism in the pulse of college students. Enhance their sense of belonging and pride to the great Chinese nation, enhance their patriotic awareness and adjust the spirit of cooperation, so that they can always maintain a healthy and positive mental state in their daily study and work.

\section{Conclusion}

In a word, as a department of Ideological and political education in Colleges and universities, it is necessary to follow up the needs of teaching reform in higher education, meet the requirements of students for practical teaching, have the courage to break through and innovate, and push the teaching research of Ideological and political theory course to a higher level.

\section{Acknowledgments}

Ideological and moral cultivation and achievements in the construction of applied model courses of legal basis.

\section{References}

[1]. Zhou Ji. Cultivate tens of millions of high skilled talents and run higher vocational education satisfying the people -- Speech at the third national higher vocational education industry university research integration experience exchange meeting [Z]. 2014-02-28.

[2]. song Liping. Exploration of Ideological and political education of Higher Vocational College Students under the mode of combination of work and study [J]. Vocational and technical education, 20108, (29).

[3]. Chen Haiming. The development and connotation of the talent training mode of "combination of work and study" in Higher Vocational Education [J]. Science and Education Park, 2017 (2). 
[4]. Gu Yumin. Pushing forward the reform and construction of Ideological and political theory course with innovation spirit [J]. Ideological and political education, 2016, (3).

[5]. Yan Jiazhen. Thinking on practical teaching of Ideological and political theory in Higher Vocational Education [J]. Journal of Xiamen Radio and Television University, 2015, (1). 